\title{
A települési egyenlőtlenségek új dimenziója: a mezőgazdasági földhasználat-szerkezet
}

\section{The new dimension of settlement inequality: the agricultural land use structure}

\section{GYŐRI ÁGNES, KOVÁCH IMRE}

GYőRI Ágnes: tudományos munkatárs, Társadalomtudományi Kutatóközpont, Szociológiai Intézet; 1097 Budapest, Tóth Kálmán u.4.; gyori.agnes@tk.hu; https://orcid.org/ 0000-0003-3154-3043

KOVÁCH Imre: kutatóprofesszor, Társadalomtudományi Kutatóközpont, Szociológiai Intézet; 1097 Budapest, Tóth Kálmán u.4.; egyetemi tanár, Debreceni Egyetem, Politikatudományi és Szociológiai Intézet; 4032 Debrecen, Egyetem tér 1.; kovach.imre@tk.hu; https://orcid.org/0000-0002-3966-1274

KULCSSZAVAK: földhasználat-szerkezet; látens profilelemzés; településfejlettségi különbségek

ABSZTRAKT: Tanulmányunk célja a magyarországi települések földhasználat-szerkezet szerinti csoportjainak kimutatása, és annak vizsgálata, hogy van-e összefüggés a települések fejlettségi mutatói és a földhasználat szerkezete között. Annak ellenére, hogy a földhasználat széles körben kutatott, kevés olyan elemzést találunk, amely települési szintű adatokra épül. Kutatásunk hozzáadott értékét az adja, hogy - eltérve a szakirodalom adathasználatától - megfigyelési egységnek a települést tekinti. Elemzésünk során első lépésben az EU egységes területalapú támogatási (SAPS) adatok alapján a földhasználó gazdaságok adatbázisát alakítottuk ki, majd ez alapján hoztunk létre egy településszintű adatbázist, melyet összekapcsoltunk településsoros mutatókkal. Látens profilelemzés segítségével a földhasználat-szerkezet szerint a települések hat jellegzetes csoportját tártuk fel, amelyek a korábbi kvalitatív munkák szerint is jól azonosíthatóak. A települések fejlettségi mutatóinak a földhasználat-szerkezettel történő összekapcsolása arra mutatott rá, hogy a vegyes, a szegmentált és a nagybirtok dominanciájú földhasználat-szerkezeti struktúra olyan településekre jellemző, amelyek fejlettségi mutatói rendre meghaladják a szétaprózott földhasználati szerkezetű települések mutatóit. A települések földhasználat-szerkezete további kutatásokat igényel, az azonban már most is megállapítható, hogy a települések közötti egyenlőtlenségek egy olyan lényeges dimenzióját sikerült bemutatni, amely a kutatásokban eddig kevéssé kapott figyelmet.

Ágnes GYŐRI: research fellow, Institute for Sociology, Centre for Social Sciences; Tóth Kálmán u. 4., H-1097 Budapest, Hungary; gyori.agnes@tk.hu; https://orcid.org/0000-0003-3154-3043

Imre KOVÁCH: research professor, Institute for Sociology, Centre for Social Sciences; Tóth Kálmán u. 4., H-1097 Budapest, Hungary; professor, Department of Sociology and Social Policy, University of Debrecen; Egyetem tér 1., H-4032 Debrecen, Hungary; kovach.imre@tk.hu; https:// orcid.org/0000-0002-3966-1274

KEYWORDS: land use structure; latent profile analysis; settlement inequality

ABSTRACT: The aim of our study is to analyse the groups of land use by structure in Hungarian settlements and to examine whether a correlation exists between the development indicators of

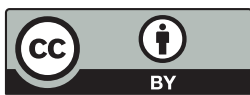


settlements and the structure of land use. Despite extensive research on land use as well as the structure of land ownership and a number of research aimed at examining the social characteristics of land users, we find few analyses based on settlement-level data. The added value of our research is that departing from the use of data in the literature, it considers the settlement as an observation unit. In the first step of our analysis, we developed a database of land-using farms based on the EU Single Area Payment Scheme (SAPS) data, and then we created a settlement-level database based on this, which was linked to settlement-row indicators. Using latent profile analysis, we identified six characteristic groups of settlements according to the structure of land use, which can be well identified according to previous qualitative works.

The geographical location of each land use type is rather mixed, however, some clear spatial distributions can be described. The dominance of large estates is typical in Transdanubia and in a part of small and medium-sized towns in the Great Plain. The segmented land use structure, in which large estates also play a major role, is most present in the smaller and medium-sized towns of the Great Plain. The mixed structure is dominant in the north-eastern part of the area between the Danube and the Tisza. The dominance of small, medium and dwarf farms is the predominant land use of the small villages of Transdanubia and the Northern Central Mountains. Case studies using qualitative methods warn that elements of local economic traditions that survive in both the socialist and post-socialist eras may have influenced the current land use structure in some settlements.

The characteristics of the settlement clusters were examined according to socio-demographic, social housing and living conditions, economic and labor market, infrastructural and environmental indicators. The combination of the development indicators of the settlements with the land use structure showed that the mixed, segmented and large land dominance structure is characteristic of settlements whose development indicators exceed the indicators of the settlements with a fragmented land use structure. The dominant presence of larger holdings is mostly associated with higher values of development indicators. The structure of land use in settlements requires further research, but it can already be stated that an important dimension of inequalities between settlements has been presented, which has received little attention in research so far.

\section{Bevezetés és szakirodalmi háttér}

Írásunk célja a magyarországi földtulajdon- és földhasználat-struktúra és a települések gazdasági-társadalmi-infrastrukturális jellemzői közötti kapcsolat vizsgálata. A tanulmány megközelítésmódja és módszere egyedinek számít a hazai és - ismereteink szerint - a nemzetközi irodalomban egyaránt.

A földhasználat és földtulajdon fogalmai kapcsán fontos kiemelnünk, hogy a föld tulajdonosa és a föld tényleges megmüvelője egyetlen korszakban sem volt feltétlenül ugyanaz a jogi vagy magánszemély. A rendelkezésre álló statisztikai adatok alapján, a földbérlet kiterjedt rendszere és a föltulajdonjog részbeni rendezetlensége miatt (például az osztatlan közös tulajdon esetében) ma sem lehet teljes egészében ezt a kettőséget tisztázni. A tanulmányban a földhasználat-szerkezet kifejezést használjuk, amelyet megenged a felhasznált adatforrás jellege (erről részletesebben lásd a következő fejezetet). Ugyanakkor azt is szükséges hangsúlyoznunk, hogy a szakirodalomban a „földhasználat” és még inkább angol megfelelöje, a „land-use” változatos tartalmakat foglal magába. Vonatkozhat többek között a tulajdonszerkezetre, üzemstruktúrára, a művelési ágakra, a termelt növénykultúrák jelzésére, a biotermelés elterjedésének követésére, a városi me- 
zőgazdaság elemzésére. A mezőgazdasági termelés üzemi struktúrái, a gazdálkodási/művelési ágazat, a domborzati és éghajlati viszonyok, a kialakult termelési kooperációk, termelési vertikumok és piaci kapcsolatok mind hatással lehetnek arra, hogy egy gazdaságnak mekkora földterületet lehet/szükséges használnia.

Mi ebben a tanulmányban földhasználat-szerkezeten a földet művelő gazdaságok földterületének nagyság szerinti megoszlását és a használt földterület nagyság szerint eltérő kombinációinak tipikus csoportjait értjük, amelyeket magyarországi településeken vizsgálunk. A településfejlettségi különbségek és a mezőgazdálkodás tipikus birtoknagyság-kombinációinak összefüggéseit keressük, ami jelentősen eltér a szakirodalmi feldolgozások adathasználatától.

A mezőgazdasági átalakulás és ennek egyik kitüntetett területe, a földtulajdonviszonyok és a föld megművelésének megoszlása a gazdaságok nagysága és tulajdonjellege szerint (például családi gazdaság, társas vállalkozás) érthető okokból kerültek a vidékkel foglalkozó társadalomtudományi kutatások központjába, amelyek a földdel kapcsolatos változások széles körét rögzítették. Csak néhány példát kiemelve elsősorban a szociológiai irodalomból: gyorsan sor került a földreprivatizáció kivitelezésének és összetett hatásainak elemzésére (Harcsa, Kovách, Szelényi 1994, 1998; Varga 2004), majd az új földhasználati viszonyok inkább politikai szempontokat, mint gazdasági vagy társadalmi hasznosságot követő indítékainak bemutatására (Csite, Kovách 1997; Juhász 2006). Az új földbirtokés földbérletrendszer jellegzetességeinek (Burgerné 1996), a kárpótlás eredeti céljai meghiúsulásának leírásai (Kovács 1994; Csite et al. 2002) is megjelentek, jószerivel a valós eseményekkel egyidőben. A kutatásokból a szövetkezetek felbomlása és korábban művelt földjeik sorsa (Kovács, Bihari 2000; Csite, Kovách 2002) és a családi gazdaságok földhasználatának gyors differenciálódása is nyomon követhető (Harcsa 1994, 1995; Harcsa, Kovách 1996; Kovács, Bihari 1998, 2000). Kovács Katalin (2007) nemzetközi összehasonlításban mutatta ki a földhasználat centralizációjának nagyságát, amely a meghirdetett politikai szándékok ellenére a jelenkorig fennmaradt (Kovách 2012, 2016a, 2018). Egy tanulmánykötet (Kovács 2016) írásai gazdag körképet adtak a földhasználat szerkezetéről (Csurgó, Kovách, Megyesi 2016), valamint olyan elemeiről, mint a munkaerő (Koós 2016), az idénymunkafelhasználás és az új típusú szövetkezések (Hamar 2016 a,b), valamint kilenc mikrokörzet, illetve település földtulajdonviszonyairól. A föld sorsa a faluszociológia állandó témája maradt (Váradi 2007). Míg korábban fóként az új egyenlőtlenségek és a szegénység forrásaként tematizálták (Csite, Kovách 1997), később a network (Megyesi 2012), az autoriter rezsim felépítése (Gonda 2019) és a populizmus (Czibere, Kovách 2021), valamint a nagybirtokok kialakulása (Mikle 2020; Mikle, Randelli 2020) is a földdel kapcsolatos kutatások témájává vált.

A földhasználat és a földtulajdon szerkezetének, a kis- és nagybirtokok megoszlásának elemzése, a földhasználók társadalmi jellemzőinek bemutatása regionális, országos vagy európai adatok szintjén majdnem minden esetben az egyéni adatokat használja abban az értelemben, hogy megfigyelési egysége a 
gazdaság. Tanulmányunk ezen kíván változtatni, mert megfigyelési egységnek a települést tekinti.

Dolgozatunkban az adatok és a módszerek bemutatását követően a mezögazdasági területek településenként értelmezett használati szerkezete alapján azonosítjuk a magyarországi települések homogén csoportjait. Második lépésben kapcsolatot keresünk a földhasználat-szerkezet szerint azonosított településklaszterek és a települések különböző dimenziókban mért fejlettségi mutatói között. Milyen társadalmi, gazdasági és infrastrukturális adottságokkal jár együtt Magyarországon a települések földhasználat-szerkezete? Vajon összefügg-e az erősen koncentrált földhasználat a települések gazdasági-társadalmi-infrastrukturális fejlettségével? Amennyiben igen, a magyarázatok között mely mutatóknak van kitüntetett szerepe?

\section{Adatok és változók}

Az általunk használt adatok két forrásból származnak. Egyrészt az EU 2014-es egységes területalapú támogatás (SAPS) adatait használtuk, amely alapján egy egyéni - földhasználói - szintű adatbázist hoztunk létre, amelyet a következő lépésben átforgattuk egy települési szintű adatbázissá, végül ezt kapcsoltuk össze településsoros demográfiai-társadalmi-gazdasági háttérváltozókkal KSH és más adatforrásokból.

A SAPS támogatási lista adatainak elemezhetővé tétele Kovách Imre munkája (részletes leírásához lásd Kovách 2016a, 46-56.). A létrehozott adatbázis a területalapú támogatásban részesült mezőgazdasági egyéni gazdaságok és szervezetek nyilvánosan elérhető legutóbbi, 2014-es listáján alapul, ${ }^{1}$ mely a birtokrekonstrukciós eljárás, azaz az egy címre bejelentett - így egy családhoz, azonos gazdasághoz tartozó - földek összevonása után ${ }^{2} 166581$ támogatott gazda nevét és bejegyzett címét tartalmazza a kapott SAPS-támogatás összegével. Mivel a vizsgált évben egy hektárra 70702 forint támogatást lehetett igényelni (16/2014. (X. 15.) FM rendelet a 2014. évi egységes területalapú támogatás, valamint a különleges tejtámogatás összegének megállapításáról), a kapott területalapú támogatás összegéből visszakövetkeztethető (egyszerű osztással kiszámítható) az egyes gazdák által megművelt mezőgazdasági terület nagysága (1. táblázat). Mivel a gazdák neve és lakcíme nyilvánosan hozzáférhető internetes adatbázisban szerepelt, így jogi és technikai értelemben is lehetőség volt arra, hogy az egy háztartáshoz köthető földhasználat nagyságát interjúkkal ellenőrizzük. A kiválasztott 30 esetben nem volt szignifikáns eltérés az adatbázisban szereplő, illetve a gazda által közölt adatok között. Az adatbázis jellegzetessége, hogy abban a földhasználók lakcímének/székhelyének címe és nem a művelt föld közigazgatási elhelyezkedése szerepel. Azt nem lehet tudni, hogy ennek milyen és mekkora hatása van a települések szerint megállapított földhasználat-szerkezet szempontjából, de az 
1. táblázat: A gazdaságok száma és megoszlása a használat földnagyság-kategóriái szerint Number and distribution of farms by size of land

\begin{tabular}{lcc}
\multicolumn{1}{c}{ Birtokkategória $(\mathrm{ha})$} & Gazdaságok száma $(\mathrm{db})$ & Gazdaságok megoszlàsa $(\%)$ \\
\hline 5,0 alatt & 81074 & 48,7 \\
$5,1-10,0$ & 29002 & 17,4 \\
$10,1-25,0$ & 27584 & 16,6 \\
$25,1-50,0$ & 12624 & 7,6 \\
$50,1-200,0$ & 12174 & 7,3 \\
200,0 felett & 4123 & 2,4 \\
Összesen & 166581 & 100,0 \\
\hline
\end{tabular}

Forrás: 2014-es SAPS-lista adatai alapján saját számitás

interjúk és a hivatkozott kvalitatív tanulmányok szerint az adatokban szereplő földhasználat-szerkezet és a terepmunkával szerzett, természetükből eredően nem reprezentatív, kvalitatív információk között nincs nagyobb eltérés. A használt adatbázis nem alkalmas a több településre is kiterjedő birtokok kezelésére, de ezzel nagyrészt a KSH gyakorlata is adós.

A nyilvántartási rendszer és a SAPS támogatási elveinek változásai miatt ez az adatbázis 2015-től nem használható a támogatottak teljes körére vonatkozó adatbázis létrehozására, mert a támogatási rendszer változásai miatt 2015-től az egy hektárra eső támogatás nagysága a birtok méretének függvénye, míg korábban az egy hektárra eső támogatás mértéke birtokmérettől függetlenül egységes volt. A 2014-es kimutatás sem hozzáférhető már, így tanulmányunk adatbázisa egyedülálló a maga nemében. A tanulmányunkban használt adatokból kimutatható földhasználat-szerkezet csak kevéssé változott 2015 után, és az alapvető trendek megegyeznek a KSH által jelzettekkel, ugyanakkor a SAPS-adatok erőteljesebb koncentrációt mutatnak (Kovách 2016a).

A következő lépésben a fent bemutatott, egymást kizáró földnagyság-kategóriákat dichotóm változókká alakítva települési szintre aggregáltuk, hogy településenként vizsgálni tudjuk az egyes kategóriákba tartozó gazdaságokat. Az aggregált adatbázis 3105 település adatait tartalmazza, ez a teljes magyarországi településállomány 98,5 százaléka. Elemzésünkben tehát az a 49 település nem szerepel, ahol 2014-ben területalapú támogatást nem igényeltek és/vagy nem kaptak egyéni gazdaságok, illetve szervezetek, továbbá Budapestet kihagytuk az elemzésből. Megnéztük, hogy (1) egy településen az adott földnagyság-kategóriába hány gazdaság tartozik, és azt, hogy (2) összesen mekkora földterületet müvelnek az egyes kategóriákba tartozó gazdák, végül kiszámoltuk, hogy (3) a település összes mezőgazdasági földterületéből mekkora arányt tesz ki az adott birtoknagyság-kategóriába tartozó földek összes területe. A megoszlások alapján a földnagyság-kategóriák számát tovább csökkentettük úgy, hogy a 25 hektár alattiakat egyetlen kategóriába vontuk, így végül négy birtoknagyság-kategóriával dolgoztunk. 
Érdekességképpen megemlítjük, hogy a települések nyolcadában (12,4\%, N=384) kizárólag 25 hektár alatti gazdaságok működnek, és 22 olyan település található az országban, ahol nincs egyetlen kisebb birtok sem (és ez utóbbi csoporton belül összesen négy olyan települést ${ }^{3}$ regisztráltunk, ahol 200 hektár feletti gazdaságok művelik a teljes területet).

Mivel tanulmányunk központi kérdése a települések földhasználat-szerkezetének és a települési sajátosságok kapcsolatának vizsgálata, ezért adatbázisunkat összekapcsoltuk településsoros társadalmi-gazdasági-infrastrukturális és egyéb háttérváltozókkal más adatforrásokból (TeIR, T-STAR és NAV adatbázisokból származó települési mutatókkal).

\section{A települések csoportjai földhasználat-szerkezetük alapján}

A települések földhasználat-szerkezet alapján kirajzolódó típusait modell alapú klaszterezés segítségével tártuk fel. Arra voltunk kíváncsiak, hogy a települések milyen jól körülírt típusai azonosíthatóak a földhasználat-szerkezet alapján. A kérdés megválaszolásához a 25 hektár alatti, a 25,1 és 50 hektár közötti, az 50,1 és 200 hektár közötti, valamint a 200 hektár feletti birtoknagyság-kategóriákba tartozó gazdaságok által művelt földeknek az adott település összes mezőgazdasági területén belüli arányát mérő változók felhasználásával képeztünk csoportokat. ${ }^{4}$

A csoportképző-változóink mindegyike magas mérési szintű, ezért a „látens profilelemzés" (LPA) eljárást (Collins, Lanza 2010) alkalmaztuk a településcsoportok létrehozásához (R programnyelv Mclust csomagjának felhasználásával). ${ }^{5} \mathrm{~A}$ különböző szempontok mérlegelése után (illeszkedési mutatókat: Bayesian információs kritériumot [BIC] és Akaike információs kritériumot [AIC], a keresztklasszifikáció minimumát, a BIC érték csökkenésének dinamikáját, a létrejött csoportok nagyságát és értelmezhetőségét vettük figyelembe) a 6 csoportos megoldást fogadtuk el. Az elemzés során 2-7 csoportos megoldásokat becsültünk meg. Az AIC és a BIC mutató folyamatosan csökkent a csoportok számának növekedésével, a csökkenés mértéke azonban már mérséklődött a 6 osztályos megoldás után. A Lo-Mendell-Rubin-adjusted likelihood ratio (LMR) teszt a 7 klaszteres megoldásnál már nem szignifikáns ( $\mathrm{p}<0,05)$, ami azt jelzi, hogy a 7 klaszteres struktúra nem jobb a 6 klaszteresnél. Az egyes klaszterek nagyságát az 1. ábra mutatja.

A hat klaszter számaránya a településállományon belül 7,3 \% és 22,4\% között alakul, vagyis a legnagyobb és legkisebb alcsoport között nagyjából háromszoros a különbség, ami statisztikai szempontból megfelelően kiegyensúlyozott csoportosításnak tekinthető.

A két legnagyobb és szinte azonos elemszámú, 3. és 6. klaszterbe a települések valamivel több mint ötöde (21,5\% és 22,4\%-a) tartozik (N3=667, N6=696), a két középső klaszter (2. és 5. klaszter) hasonlóan közepes méretű 16,7 és 16,8 százalé- 
1. ábra: A magyarországi települések csoportosítása a földhasználatszerkezet-mutatók alapján, \% Clusters of settlements in Hungary according to the land use structure \%

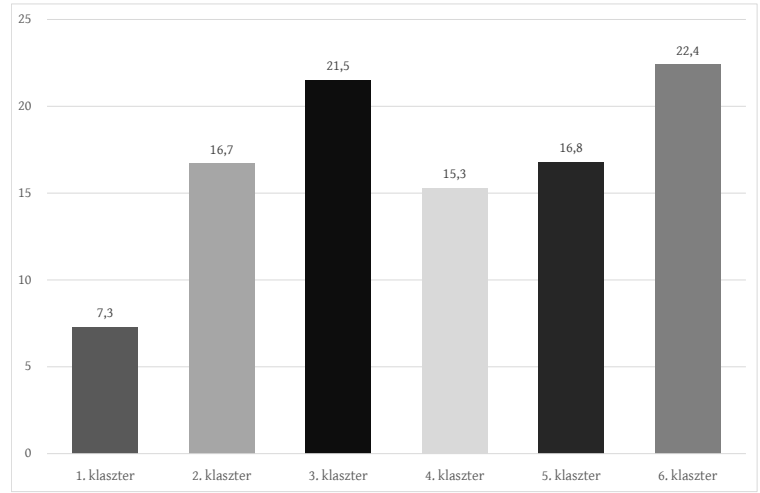

Forrás: 2014-es SAPS-lista adatai alapján saját számítás

kos aránnyal (N2=519, N5=523), a 4. klaszter a települések valamivel több mint hetedét tömöríti (N4=474), és végül kirajzolódik a legkisebb méretü csoport, az 1. klaszter, melyben a települések 7,3 százaléka található (N1=227). Az egyes klaszterek jellemzőit a 2. táblázat tartalmazza.

Az elsö, a legkisebb méretü településklaszter sajátossága, hogy az ide tartozó települések földterületének legnagyobb hányadát a 25-50 hektár közötti gazdaságok használják, további jellemzője - bár jóval kisebb mértékben - a 25 hektár alatti gazdaságok jelenléte, míg a többi birtoknagyság nincs jelen. Ezt a klasztert - az uralkodó földbirtok-kategória alapján - „kisbirtok” profilú csoportnak neveztük.

2. táblázat: A földhasználat-szerkezet településcsoportjainak megoszlása és a

klaszterképző indikátorok átlagai

Distribution of settlement groups in the land use structure and averages of cluster indicators

A jolanasznaıat-szerкеzег teıерuıеscsoportjal
1.
2.
3.
4.
5.
6.

\begin{tabular}{ccccccc} 
& Kisbirtok & Középbirtok & Nagybirtok & Törpebirtok & Vegyes & Szegmentált \\
\hline$\%$ & 7,3 & 16,7 & 21,5 & 15,3 & 16,8 & 22,4 \\
$\mathrm{~N}$ & 227 & 519 & 667 & 473 & 523 & 696 \\
\hline
\end{tabular}

Az egyes birtoknagyság-kategóriákba tartozó gazdaságok által müvelt földeknek a település összes mezögazdasági területén belüli aránya (\%)

\begin{tabular}{lrrrrrr}
\hline 25 alatt & 39,64 & 18,42 & 7,76 & 95,11 & 38,82 & 16,65 \\
$25-50$ & 58,95 & 8,70 & 4,27 & 3,82 & 19,70 & 9,45 \\
$50-200$ & 1,35 & 71,60 & 9,59 & 0,99 & 38,22 & 28,66 \\
200 felett & 0,06 & 1,28 & 78,38 & 0,08 & 3,26 & 45,24 \\
\hline
\end{tabular}

Megjegyzés: Klaszterek elnevezése a domináns földbirtok-kategória alapján Forrás: 2014-es SAPS-lista adatai alapján saját számítás 
A 2. klaszterben egyértelmű a „középbirtokok” dominanciája, ugyanis az itt található települések mezőgazdasági földterületét jellemzően az 50-200 hektár közötti gazdaságok művelik (72\%-át), a többi földterületet pedig a 25 hektár alatti kisgazdaságok (18,4\%-át) és a 25-50 hektár közötti paraszti gazdaságok (8,7\%-át).

A 3. - az egyik legnagyobb elemszámú - klaszterbe tartozó települések mezőgazdasági földterületének legnagyobb hányada a 200 hektár feletti gazdaságok használatában van, míg a többi birtoknagyság-kategóriába tartozó gazdaságok által használt földterület településen belüli aránya csak néhány százalékot (4-9\%-ot) tesz ki. Ez a településcsoport tehát a „nagybirtok” dominanciájával írható le. Gyermely és környéke földhasználatának története mutatja meg a nagybirtok kialakulásának az egyik útját. A ma már több mint 10000 hektáron gazdálkodó nagyüzem a szövetkezeti formában működő élelmiszeripari komplexum bázisán indította el a további terjeszkedést. Az első időszakban nagyrészt megszerezték a négy falu határában használt korábbi szövetkezeti földeket. A második szakaszban vállalatokat vásároltak fel és állami földek tartós bérletét szerezték meg, majd finanszírozták alkalmazottaik földvásárlásait, amelyekre azonnal hosszú távú bérletet kötöttek. A rendelkezésre álló pénz-, tudás- és kapcsolati tőke tette lehetővé az intenzív földfelhalmozást (Hamar 2016c). A böhönyei mikrokörzet példája is arról tanúskodik, hogy a nagybirtok kialakításának legbiztosabb hátterét a magántulajdonná transzformált szocialista nagyüzemek (állami gazdaság, illetve faluszövetkezet) jelentették, amelyek mellé a mikrokörzetben a külföldi tőkéből lépésről lépésre felvásárolt, végül 1000 hektárnál nagyobb gazdaságok sorakoztak fel (Schwarcz 2016).

Ezzel szemben a 4. klasztert a „törpebirtokok dominanciája” jellemzi: az ide tartozó települések földterületének döntő hányadát (95\%-át) kisgazdaságok (25 hektár alatti gazdaságok) művelik, emellett minimális a 25-50 hektár közötti gazdaságok által használt földterület aránya, a többi birtoknagyság-kategória pedig szinte nincs jelen. Erről a fölhasználat-szerkezeti típusról a legkevesebb az ismeretünk. Az egyértelmü, hogy a kicsi földterületek sokasága az aprófalvak egyik jellemző földhasználati szerkezete. Egy település kumulálódott hátrányai azonban a földek koncentrált használatához is elvezethettek (Kovai 2016; Németh 2016), és nem igazán világos, hogy a települések 15 százalékában az intenzív földigény ellenére miért maradt meg a törpebirtok dominanciája.

Az 5. klaszterbe tartozó települések földhasználat-szerkezete „vegyes”. Földjeiket jellemzően 200 hektár alatti gazdaságok művelik. A vegyes földhasználatú települések határában is történt földhasználat-koncentráció, de nincsenek néhány száz hektárnál nagyobb farmok. Az esetleírások alapján valószínűsíthető, hogy a vegyes földhasználat olyan régiókban jelent meg, ahol a kollektivizálás előtt meghatározó volt a dinamikus parasztgazdások jelenléte, s ennek egyfajta folytatásaként intenzív kisüzemi termelést folytattak a szocialista korszak utolsó három évtizedében is. A Duna-Tisza közén Nyársapát (Hamar, Kovács, Váradi 2016), Kiskőrös (Csurgó 2016), vagy a Tiszaháton Fehérgyarmat (Rácz 2016) földhasználatá- 
ban egyértelműen meghatározó a piaci igényekre gyorsan reagálni képes kisüzemi árutermelés.

A legnagyobb esetszámú csoportot jelentő 6. klaszterbe tartozó települések földhasználat-szerkezete „szegmentált”: a földterület döntő hányadát a 200 hektár feletti nagybirtokok és az 50-200 hektár közötti gazdaságok művelik, a földek további hatodát pedig kisgazdaságok használják. Az esettanulmányok szerint ebben a földhasználati csoportban a 1990 előtti szocialista agrárnagyüzemek privatizálása hozta létre a mai nagyüzemeket, amelyek azonban nem monopolizálták az adott településhez tartozó termőföld használatát. Ezt a földhasználati módot reprezentálja Nagykőrös és a vele szomszédos Kocsér (Hamar, Kovács, Váradi 2016), valamint Zalaszentgrót (Megyesi 2016). A nagyobb kiterjedésű határral rendelkező településeken egy-egy nagyobb, korábbi mezőgazdasági szövetkezet vagy állami gazdaság kiszervezése egyetlen magántulajdonú utódszervezetbe sem feltétlenül vezetett a nagybirtok dominanciájához a földhasználat szerkezetében. Hajdúnánáson például egy többezer hektáros nagyüzem (volt állami gazdaság) mellett más ezer hektárt meghaladó, illetve több száz hektáros gazdaság, 25-30 db 50 és 200 hektár közötti agrárüzem és néhány száz kisebb farm is működik (Kovách 2016b).

Az egyes klaszterek földrajzi elhelyezkedésének a sajátosságait vizsgálva (2. ábra) azt látjuk, hogy az 1. - a legkisebb elemszámú ( $\mathrm{N}=227)$-, a kisbirtokok dominanciájával jellemezhető településcsoportot (a települési jogállás szerint definiált) községek alkotják; az ország községeinek közel tizede (3. táblázat), melyek elsősorban

2. ábra: Magyarország települései a földhasználat-szerkezet alapján

(látens profilelemzés eredménye)

Hungarian settlements by land use structure (results of latent profile analyses)

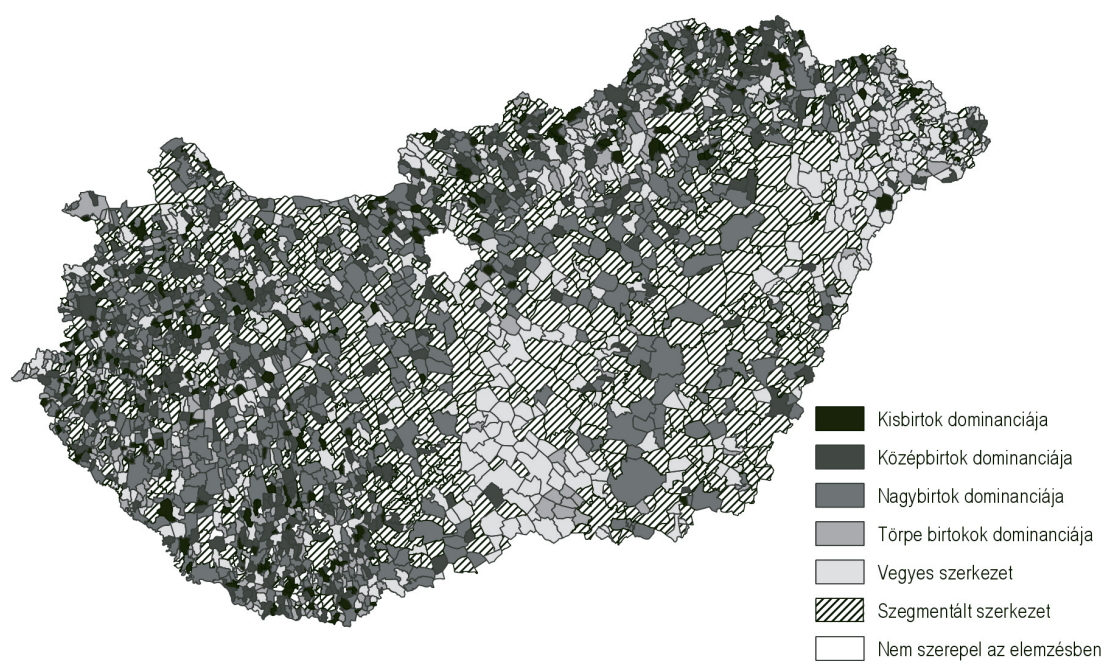

Forrás: 2014-es SAPS-lista adatai alapján saját számítás 
Nyugat- és Dél-Dunántúlon, valamint Észak-Magyarországon találhatók. A klaszterhez tartozó települések átlagnépessége 829 fö. A Vas, Zala, Veszprém megyei törpe- és aprófalvak többsége tartozik ide.

A középbirtok-dominanciájú 2. klaszterbe ( $\mathrm{N}=519)$ tartozó települések - hasonlóan az 1. klaszterhez - községek (96\%-a), melyek Észak-Magyarországon (elsősorban Borsodban, Nógrádban) és a Dunántúlon találhatók (jellemzően Veszprém, Vas, Zala és Baranya megyei aprófalvak). Ebbe a klaszterbe az előzőnél valamelyest több városi jogállású település (összesen 14) és nagyközség került, melyek átlagnépessége 1154 fö.

A nagybirtok-dominanciájú 3. klaszterben - mely a második legnagyobb méretü csoport $(\mathrm{N}=667)$ - található a megyei jogú városok zöme, a városok negyede és a nagyközségek, valamint a községek ötöde. Ide került továbbá egy megyeszékhely (Kaposvár) is. Földrajzi elhelyezkedésüket tekintve, ezt a klasztert jellemzően a Közép-, Nyugat- és Dél-Dunántúl (Fejér, Somogy, Tolna, Vas megye) települései alkotják, valamint a Tisza vonalában fekvő nagyobb kiterjedésű alföldi települések, főleg Csongrád, Jász-Nagykun-Szolnok megyékből (például olyan agrárvárosok, mint Szarvas, Szentes, Karcag, Mezőtúr, Hódmezővásárhely). Átlagnépessége 2529 fö.

A 4. klaszter, a törpebirtok-dominanciájú területek ( $\mathrm{N}=473)$ kis népességszámú és túlnyomórészt kis közigazgatási területű községekben vannak jelen (falvaink több mint hatoda), ugyanakkor az 1. és 2. klaszterhez képest valamivel több nagyközségben. Főleg dél- és nyugat-dunántúli, valamint észak-magyarországi

3. táblázat: A földhasználat-szerkezet településcsoportjainak jogállás, átlagnépesség és átlagos mezőgazdasági terület szerinti összetétele

Composition of land use structure settlement groups by legal status, average population and average agricultural area Telepulescsoportok

$\begin{array}{llllll}1 . & 2 . & 3 . & 4 . & 5 . & 6 .\end{array}$

\begin{tabular}{lcccccc} 
& Kisbirtok & Középbirtok & Nagybirtok & Törpebirtok & Vegyes & Szegmentált \\
\hline Átlagnépesség(fö) & 829 & 1154 & 2529 & 774 & 2442 & 5915 \\
$\begin{array}{l}\text { Mezőgazdasági } \\
\text { területátlagos }\end{array}$ & 124,6 & 436,3 & 2724,4 & 116,8 & 1036,5 & 3150,4 \\
nagysága (ha) & & & & & & \\
\hline Megyeszékhely & 0 & 0 & 1 & 0 & 0 & 17 \\
Megyei jogú város & 0 & 0 & 3 & 0 & 1 & 1 \\
Város & 4 & 14 & 85 & 6 & 72 & 143 \\
Nagyközség & 4 & 6 & 25 & 10 & 28 & 54 \\
Község & 219 & 499 & 553 & 457 & 422 & 480 \\
Összesen & 227 & 519 & 667 & 473 & 523 & 695 \\
\hline
\end{tabular}

Forrás: 2014-es SAPS-lista adatai alapján saját számítás 
községek kerültek ide, elsősorban Baranya, Zala, Heves és Borsod-Abaúj-Zemplén megyékből. Lakónépességük átlagosan 774 fo, de az ide tartozó települések népességének módusza csak 274 fö, vagyis e települések többségében rendkívül alacsony a lakosság száma.

A vegyes földhasználat-szerkezetű 5. klaszterbe 523 település tartozik: a városok több mint ötöde (összesen 72 város), az előző (4.) klaszterekhez képest több nagyközség, továbbá a községek hatoda és egy megyei jogú város, melyek átlagnépessége 2442 fó (szemben az 1., a 2. és a 4. klaszterekkel, alapvetően a népesebb községek tartoznak ide). Jellemzően az Észak-Alföld és Dél-Alföld régiókban helyezkednek el: leginkább Bács-Kiskun középső észak-déli sávjában, Csongrád, Szabolcs-Szatmár-Bereg megyében, Hajdú-Bihar észak-keleti területein.

A legnagyobb méretű ( $\mathrm{N}=695)$, szegmentált földhasználat-szerkezetü 6. klaszterben találhatók a megyeszékhelyek (összesen 17), a városaink közel fele (44,1\%a), és a nagyközségek kétötöde, a községek ötöde. Jellemzően dél- és észak-alföldi (elsősorban Békés, Bács-Kiskun, Hajdú-Bihar, Jász-Nagykun-Szolnok megyei) települések tartoznak ide, de Tolna megye kisközségei is felülreprezentáltak. Ez a legmagasabb átlagnépességű klaszter: az ide tartozó települések népességüket tekintve átlagosan 5915 lakossal rendelkeztek a vizsgált évben (2014-ben).

\section{Földhasználat-szerkezet és a települések fejlettsége}

Az elemzés második részében arra kerestük a választ, hogy a földhasználat-szerkezet alapján feltárt településprofilok különböznek-e gazdasági, társadalmi, infrastrukturális és egyéb települési jellemzők tekintetében. Elemzésünkhöz a SAPS támogatási lista alapján létrehozott adatbázisunkat összekapcsoltuk a TeIR, T-STAR és NAV adatbázisokból származó települési mutatókkal, és ezekből továbbfejlesztett indikátorokat képeztünk. Az általunk felhasznált mutatók döntően 2013-2014. évi adatok, vagyis arra az időszakra vonatkoznak, mint a SAPS-támogatások listája. A földhasználat-szerkezet lényegi elemei nem változtak 2014 óta, mint ahogy a települések fejlettségi mutatói sem, ezért megállapításainkat az utóbbi hét évre is érvényesnek tartjuk. Azokban az esetekben, ahol nem voltak elérhetőek 2014. évi adatok, ott a 2011. évi népszámlálási adatokat használtunk.

A településklaszterek sajátosságait 1) társadalmi-demográfiai, 2) szociális, 3) lakás- és életkörülmények, 4) gazdasági és munkaerő-piaci, valamint 5) infrastrukturális, illetve környezeti mutatók szerint vizsgáltuk. Az általunk elemzett települési szintű változók körének kialakításakor figyelembe vettük a jelenleg hatályos, hátrányos helyzetű települések lehatárolásával foglalkozó kormányrendelet (105/2015) által használt mutatókat („Kormányrendelet, a kedvezményezett települések besorolásáról és a besorolás feltételrendszeréről"), mely rendelet társadalmi, munkaerő-piaci, lakás-, illetve életkörülmények és infrastrukturális szempontok alapján határolja le a legalacsonyabb mutatókkal rendelkező telepü- 
léseket. Ugyanakkor a kormányrendeletben használt 4 indikátorcsoportot további mutatókkal bővítettük (pl. demográfiai vitalitást mutató változókkal), míg néhány mutatót kihagytunk, továbbá létrehoztunk egy új mutatócsoportot.

A települések demográfiai helyzetének általunk vizsgált változói a következők: 1) halálozási ráta - ezer lakosra jutó halálozások száma - elmúlt 5 évi átlaga; 2) vándorlási különbözet ezer lakosra, elmúlt 5 év átlaga;3) fiatal - 14 éves és fiatalabb - népesség eltartottsági rátája; 4) idős - 65 éves és idősebb - népesség eltartottsági rátája.

A szociális dimenziót négy változóval mértük: 1) védelembe vett kiskorú gyerekek aránya a 18 évesnél fiatalabb lakossághoz viszonyítva; 2) rendszeres szociális segélyben részesítettek aránya a 18 évesnél idősebb lakossághoz viszonyítva; 3) önkormányzat által nyújtott átmeneti segélyben részesítettek aránya a 18 évesnél idősebb lakossághoz viszonyítva; 4) legalább érettségizettek aránya a megfelelő korúak százalékában.

A lakás-és életkörülményeket öt változó mutatja meg: 1) használt lakások átlagos ára; 2) elmúlt 5 év során épített lakások aránya az időszak végi lakásállományból; 3) komfort nélküli lakások aránya az összes lakott lakáshoz viszonyítva; 4) egy állandó lakosra jutó SZJA-alapot képező jövedelem; 5) természetes személyek által üzemeltetett személygépkocsik kor szerint súlyozott - ezer lakosra jutó - száma.

A helyi gazdasági és munkaerö-piaci helyzetet öt változó írja le: 1) foglalkoztatottsági ráta; 2) nyilvántartott álláskeresők aránya a munkaképes korú állandó népességből; 3) tartósan nyilvántartott álláskeresők aránya a munkaképes korú állandó népességből; 4) legfeljebb általános iskolát végzett nyilvántartott álláskeresők aránya; 5) működő vállalkozások ezer lakosra jutó száma; 6) önkormányzatok helyi adóbevételének aránya a tárgyévi bevételekből.

Végül az alábbi változók irányulnak a települési infrastruktúrára, illetve környezetre: 1) közüzemi szennyvízgyűijtő-hálózatba kapcsolódott lakások aránya; 2) szélessávú internet-előfizetők ezer lakosra jutó száma; 3) kiépített utak aránya az összes önkormányzati fenntartású közútból; 4) megyeszékhely elérésének mutatója (perc); 5) gyorsforgalmi csomópontok elérési mutatója (perc); 6) intézményi ellátottság mértéke. ${ }^{6}$

A településeket a különböző dimenziók mentén leíró 25 változóból - az ellentétes értéktartalmú mutatók egy irányba fordítása ${ }^{7}$ és azonos terjedelmű skálára transzformálása után - statisztikai adatsűrítési eljárással (főkomponens-elemzéssel) ${ }^{8}$ olyan mutatókat képeztünk, melyek a demográfiai, a szociális, a lakás- és életkörülmények, a gazdasági és munkaerő-piaci, valamint az infrastruktúra dimenzióiban mérik a települések egyenlőtlenségeit, ahol a minél magasabb érték az adott dimenzión belüli jobb helyzetet mutatja. Azaz az új, aggregált változók negatív, „alacsony” értékei kedvezőtlenebb, míg a pozitív értékek az országosnál jobb helyzetet tükröznek. ${ }^{9}$

Az eltérő földhasználat-szerkezeti profilú településklaszterek közötti különbségeket az egyes indikátorcsoportok szerint képzett mutatók szerint (3. ábra és Melléklet 1. táblázat) vizsgálva azt látjuk, hogy a legjobb helyzetű klaszter - a 
demográfiai dimenzió kivételével - a szegmentált földhasználat-szerkezetü 6. klaszter, és ezt követi a nagybirtok- dominanciájú 3. klaszter. Míg az egyes dimenziók tekintetében (szintén a demográfiai komponens kivételével) a legalacsonyabb értékekkel rendre a törpebirtokklaszter rendelkezik.

3. ábra: A településklaszterek különbségének alakulása az egyes dimenziókban (átlagértékek) Differences of settlement clusters in each dimension (average values)

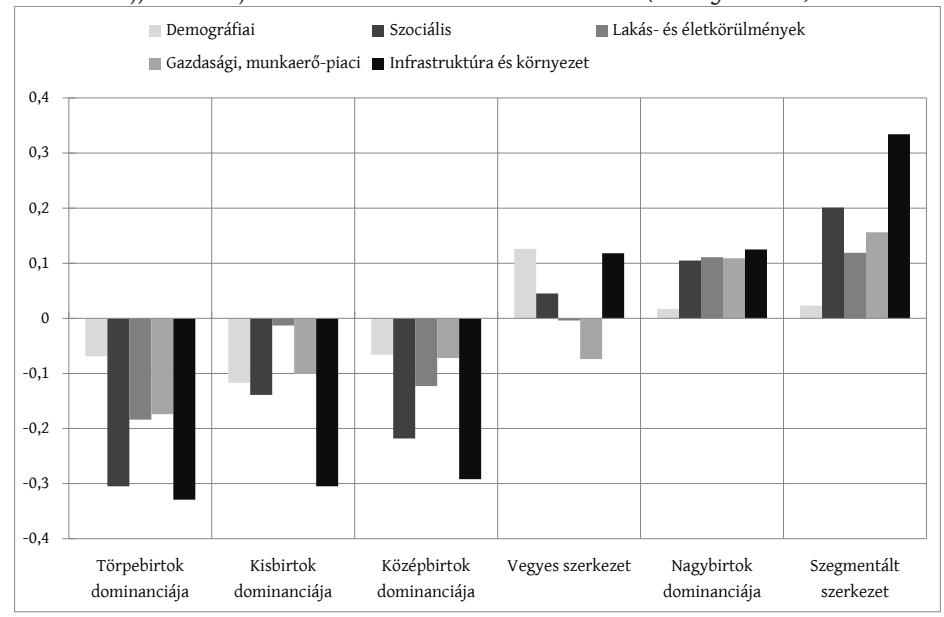

Forrás: 2014-es SAPS-lista adatai alapján saját számítás

Amennyiben a klasztereket az egyes dimenziók itemei alapján külön-külön vizsgáljuk, részletesebb különbségek rajzolódnak ki a települési profilok között (az egyes mutatók szerinti részletes eredményeket, a klaszterek átlagértékeit és szórását lásd a Melléklet 2-5. táblázataiban). ${ }^{10} \mathrm{Nem}$ meglepő, hogy a szegmentált földbirtok-szerkezetü (6.) klaszter, mely a megyeszékhelyek és a városi jogállású települések zömét foglalja magába, a többi klaszterhez képest kiugróan magas infrastrukturális mutatókkal rendelkezik az intézményi ellátottság, a közüzemi szennyvízgyüjtö-hálózathoz kapcsolt lakások, a szélessávú internet-előfizetők, a szelektív gyűjtéssel elszállított hulladék vagy akár a kiépített út, illetve köztér arányát tekintve. Jóllehet a közlekedési-elérési mutatók nem ebben a klaszterben a legkedvezőbbek, sőt a megyeszékhely elérési mutatója átlag alatti. Ugyanez a kedvező helyzet igaz a legtöbb - általunk vizsgált - gazdasági, munkaerő-piaci, szociális, lakás- és életkörülményeket leíró változó tekintetében is: itt a legmagasabb a foglalkoztatási ráta és legalacsonyabb a munkanélküliek, illetve szociális segélyezettek aránya, legkedvezőbbek a jövedelmek, legmagasabb az összkomfortos és közcsatorna-hálózatba bekötött lakások aránya. Ugyanakkor a klasztert a magas népességszám mellett minimális - az átlagnál kisebb mértékủ - természetes fogyás jellemzi, demográfiai vitalitása átlag alatti.

A nagybirtok-dominanciájú (3.) klaszter mutatói számos esetben átlagon felüliek, de majdnem minden vizsgált változó esetében az elöző, szegmentált szerkezetủ (6.) klaszter értékei alatt maradnak. Ennek a klaszternek sajátossága a kedvező 
lakás- és életkörülmények (itt a legmagasabb az átlagos lakásár és személygépkocsik száma), valamint a vállalkozásokon belül a társas vállalkozások (rt-k, kft-k és agrárgazdasági szövetkezetek) aránya. Átlag körüli fiatalodási, illetve öregedési index és vándorlási egyenleg jellemzi.

A vegyes földbirtok-szerkezetű (5.) klaszternél a csoportindikátorok értékei - a demográfiai komponens kivételével - alacsonyabbak a 6. és 3. klasztereknél. Ez a településcsoport lényegében „átlagosnak” tekintheto, mivel értékei nagyjából az átlagok körül mozognak. Ez alól kivételt jelentenek a kedvező társadalmi-demográfiai mutatók: a többi klaszterhez képest itt a legkedvezőbbek a gyerekekre és az idősekre számított eltartottsági ráták, valamint a vándorlási egyenleg értéke.

A közép-, a kis-és a törpebirtok-dominanciájú klaszterekbe (a 2., az 1. és a 4. település csoportokba) az átlagosnál kedvezőtlenebb helyzetü települések kerültek. A 2., a középbirtok-dominanciájú klaszter a kis- (1.) és a törpebirtok-dominanciájú (4.) klaszterhez képest a gazdaság és az infrastruktúra dimenziójában kedvezőbb értékekkel rendelkezik; viszont a lakás- és életkörülmények, valamint a szociális dimenzió értékei kedvezőtlenebbek a kisbirtok-dominanciájú klaszternél.

A kisbirtok dominanciájával jellemzett 1. klaszter karakterisztikáját tekintve a demográfiai dimenzióban a legrosszabb helyzetű településcsoport - jóval az átlag és a többi klaszter alatti eltartottsági és halálozási rátákkal. Ugyan a lakás- és szociális dimenziókban kissé kedvezőbb értékekkel rendelkezik, mint a 2. klaszter, de néhány mutató jóval az átlag alatt alakul: például itt a legalacsonyabb az elmúlt öt évben épített lakások és a kiépített utak aránya.

A törpebirtok-dominanciájú (4.) klaszter - a demográfiai helyzetre vonatkozó, a kisbirtok-szerkezetű klaszternél kissé kedvezőbb mutatókon kívül - összességében a legrosszabb helyzetü településcsoport. A többi klasztertől leginkább a munkaerő-piaci, a szociális, a lakás- és életkörülményeire vonatkozó mutatók kedvezőtlen értékei különböztetik meg. Az ebben a klaszterben található településeken a legalacsonyabb a foglalkoztatási ráta; itt a legmagasabb a munkanélküliek aránya (mind a tartósan, mind a fizikai foglalkozású álláskeresők esetében), a védelembe vett gyerekek, a rendszeres és átmeneti segélyben részesítettetek aránya; míg itt legalacsonyabb az átlagos jövedelem, a lakásár, a komfortos és a közcsatorna-hálózatba bekapcsolt lakások aránya. Mindezek mellett az intézményi ellátottság tekintetében is a legrosszabb helyzetű csoportról van szó: az átlagnál 69\%-kal alacsonyabb az ellátottsági mutató, valamint ide került a szolgáltatási alapfunkciókkal (háziorvos, általános iskola, vegyesbolt) sem rendelkező kistelepülések többsége (29\%-a), ${ }^{11}$ bár közlekedési szempontból nem ez a leginkább szegregált klaszter.

A települések fejlettségi mutatóinak összekapcsolása a földhasználat-szerkezettel azt mutatja, hogy a nagyobb birtokok domináns jelenléte többnyire együtt jár a fejlettségi mutatók magasabb értékeivel. Ezen összefüggés kimutatása tanulmányunk egyik olyan újdonsága, amelynek megértése további kutatómunkát kíván. A nagyobb településeken, amelyek fejlettségi mutatói a magyarországi körülmények miatt eredendően jobbak, a mezőgazdasági területek is nagyobbak, és jobb 
eséllyel lehetett nagyobb üzemméretet kialakítani. Mindez azonban önmagában nem ad magyarázatot a fejlettség/földhasználat-szerkezet tendenciáinak megfigyelt egybeesésére, hiszen a falvak több mint fele tartozik a nagybirtok-dominanciájú, és a nagybirtok jelenlétét magába foglaló szegmentált földhasználat-típushoz, illetve a városok harmadában nincs meghatározó szerepe a nagybirtoknak. A kvalitatív módszerekkel készített esettanulmányok ugyanakkor arra figyelmeztetnek, hogy a lokális gazdasági tradíciók szocialista és posztszocialista korszakon átíveló, továbbélo" elemei a települések nagyobb részében lehettek hatással a jelenlegi földhasználat-szerkezetre, mint azt eddig a kutatások feltételezték.

\section{Összegzés}

A tanulmány két fó célkitűzése az volt, hogy megtaláljuk a települések földhasználat-szerkezet szerinti legjellemzőbb csoportjait, illetve, hogy a települések fejlettségi mutatói és a földhasználat alapján kialakított csoporthoz tartozásuk közötti statisztikailag kimutatható kapcsolatokat feltárjuk. Hangsúlyozzuk, hogy kutatásunknak nem volt célja ok-okozati összefüggések feltárása, csupán a változók „együttmozgásának” vizsgálatára vállalkozott. Eredményeink nem nyújtanak szigorú értelemben vett oksági magyarázatokat sem, ehhez longitudinális adatokon alapuló további vizsgálatok szükségesek.

A földhasználat szerkezete szerint hat jellegzetes településcsoportot találtunk, amelyek a rendelkezésre álló kvalitatív, leíró munkák információi szerint is jól azonosithatóak. Az egyes településszintü földhasználati típusok földrajzi elhelyezkedése meglehetösen kevert, ugyanakkor néhány jól kivehető térbeli megoszlás is leírható volt. A nagybirtok dominanciája a Dunántúlon és az alföldi kis- és középvárosok egy részében jellemző. A szegmentált földhasználat-szerkezet, amelyben szintén nagy súllyal szerepelnek a nagybirtokok, az Alföld kisebb és közepes városaiban vannak a leginkább jelen. A vegyes szerkezet Észak- Keleten és a DunaTisza közti terület középső sávjában domináns. A kis-, a közép- és a törpebirtok dominanciája a Dunántúl és az Északi Középhegység kisfalvainak uralkodó földhasználati módja.

A településcsoportok és a települések fejlettségi mutatói közötti összefüggések feltárása azzal a kevéssé várt eredménnyel járt, hogy a nagybirtok jelenléte és a fejlettségi mutatók magasabb értékei rendre együtt járnak. A vegyes, a szegmentált és nagybirtok-dominanciájú földhasználat-szerkezet olyan településekre jellemző, amelyek fejlettségi mutatói rendre meghaladják a szétaprózott földhasználati struktúrával rendelkező települések mutatóit. A jelenség értelmezésére további vizsgálatok szükségesek, ugyanakkor az talán máris kijelenthető, hogy a földhasználat-szerkezet a települési egyenlötlenségek leírásában és megértésében egy új, eddig kevéssé használt, de megkerülhetetlen dimenziót jelent. 


\section{Jegyzetek}

1 Minden termelő - megfelelő igénylés után - vissza nem térítendő támogatást kap Magyarországon (hektáronként hatvan-hetven ezer forintot évente), és mivel uniós forrásról van szó, a támogatás összege nyilvános, így a támogatott gazdák nevét és bejegyzett címét tartalmazó listák elérhetők a Mezőgazdasági és Vidékfejlesztési Hivatal honlapján 2014-ig (ezt követő évekre teljes listák már nem tölthetők le, csak egy uniós honlapon kereshetők egyénenként).

2 A birtokrekonstrukciós eljárás során 30524 gazdaság azonos címre bejelentett földjei kerültek összevonásra.

3 A Nógrád megyei Erdőtarcsa, Sajólászlófalva Borsod-Abaúj-Zemplén megyében, valamint Apátvarasd és Gödrekeresztúr Baranyában.

4 Klaszterképző változóink tehát: (1) a 25 hektár alatti gazdaságok összes földterületének a település mezőgazdasági művelés alá vont összes földjén belüli aránya (\%); (2) a 25,1 és 50 hektár közötti gazdaságok összes földterületének a település mezőgazdasági művelés alá vont összes földjén belüli aránya (\%); (3) az 50,1 és 200 hektár közötti gazdaságok összes földterületének a település mezőgazdasági művelés alá vont összes földjén belüli aránya (\%); és (4) a 200 hektár feletti gazdaságok összes földterületének a település mezőgazdasági művelés alá vont összes földjén belüli aránya (\%).

5 Az LPA a klaszterelemzéshez hasonló, diszkrét látens változók (látens csoportok) feltételezésével folytonos manifeszt indikátorok alkalmazása mellett történő modell alapú elemzés (Collins, Lanza 2010).

6 Az általunk kialakított intézményi ellátottsági mutató a településen belül elérhető szolgáltatások, intézmények létét méri, melynek értéke 0 és 24 között változhat, attól függően, hogy a településen a vizsgált intézmények közül hány érhető el: van-e bölcsőde, óvoda, általános iskola, középiskola, családi napközi, járóbeteg-szakellátás, kórház, gyógyszertár, felnőtt háziorvosi szolgálat, gyermek háziorvosi szolgálat, könyvtár, közművelődési intézmény, uszoda vagy fürdő, piac, ruházati szaküzlet, vegyesiparcikk üzlet, üzemanyagtöltő állomás, bankfiók, helyközi autóbuszmegálló, posta, rendőrség/rendőrőrs, tűzoltóság, szennyvízgyűjtő-hálózat, szennyvíztisztító-telep.

7 Annak érdekében, hogy mindegyik változó magas értékei a kedvező települési helyzetet, alacsony értékei pedig a hátrányos helyzetet tükrözzék.

8 A főkomponens-elemzés (lineáris transzformáció) az eredeti változókat nem egyszerüen összeadja, hanem az eredeti (mért) változókhoz különböző súlyokat rendel - éppen akkora súlyokat, melyekkel elérhető, hogy az új változó (a főkomponens) a lehető legtöbb információtartalmat őrizze meg az eredeti változók heterogenitásából -, majd az itemeket a súlyokkal megszorozva adja össze (Székelyi, Barna 2008).

9 Valamennyi új, aggregált változónk (főkomponensünk) az eredeti mutatók információtartalmából több mint 80 százaléknyit őriz meg, így megnyugtatóan alacsony minden esetben az információveszteség. Az aggregált mutatók kialakításához felhasznált változók belső konzisztenciájának teszteléséhez a Cronbach o mutatót használtuk, melynél a Nunnally (1978) által meghatározott 0,7-es minimum értéket vettük alapul: az öt aggregált változónk/főkomponensünk 0,8 feletti értékei jónak minősülnek.

10 A települési klaszterek sajátosságainak bemutatásakor csak a szignifikáns különbségeket emeljük ki.

11 Az alapfunkció-hiányos települések másik nagyobb hányadát (negyedét) a középbirtokdominanciájú klaszter tömöríti.

\section{Köszönetnyilvánítás}

A tanulmány elkészítéséhez köszönjük az NKFI 128965. számú kutatási projekt támogatását. 


\section{Irodalom}

Burgerné G. A. (1996): A magyarországi földpiac. Statisztikai Szemle, 5-6., 411-420.

Collins, L. M., Lanza, S. T. (2010): Latent class and latent transition analysis for the social, behavioral, and health sciences. New York, Wiley

Czibere, I., Kovách, I. (2021): State Populism in Rural Hungary. Rural Sociology, online first: 31 August 1-25. https://doi.org/10.1111/ruso.12407

Csite A., Csurgó B., Himesi Zs., Kovách I. (2002): Agrárpolitikai hatásvizsgálat": földhasználat, foglalkoztatottság, üzemszerkezet. In: Kovách I. (szerk.): Hatalom és társadalmi változás. A posztszocializmus vége. Napvilág, Budapest, 309-361.

Csite A., Kovách I. (1997): Falusi szegénység. A falu, 1., 49-54.

Csite A., Kovách I. (2002): Vidéki történet. In: Kovách I. (szerk.): Hatalom és társadalmi változás. A posztszocializmus vége. Napvilág, Budapest, 219-309.

Csurgó B. (2016): Szőlészek és borászok a Kiskőrösi kistérségben. In: Kovács K. (szerk.): Földből élők: Polarizáció a magyar vidéken. Argumentum, Budapest, 394-420.

Csurgó B., Kovách I., Megyesi B. (2016): Földhasználat, üzemtípusok, gazdálkodók. In: Kovács K. (szerk.): Földból élók: Polarizáció a magyar vidéken. Argumentum, Budapest, 34-65.

Gonda, N. (2019): Land Grabbing and the Making of An Authoritarian Populist. The Journal of Peasant Studies, 3., 606-625. https://doi.org/10.1080/03066150.2019.1584190

Hamar A. (2016a): Idénymunka a zöldség-gyümölcs ágazatban. In: Kovács K. (szerk.): Földből élők: Polarizáció a magyar vidéken. Argumentum, Budapest, 97-116.

Hamar A. (2016b): A TÉSZ-ek és a be nem teljesült várakozások. In: Kovács K. (szerk.): Földből élők: Polarizáció a magyar vidéken. Argumentum, Budapest, 117-133.

Hamar A. (2016c): Birtokszerkezet és agrárszereplők egy nem agrárjellegü térségben. In: Kovács K. (szerk.): Földből élők: Polarizáció a magyar vidéken. Argumentum, Budapest, 345-369.

Hamar A., Kovács K., Váradi M. (2016): „Azért kell a föld, hogy ha a fiam mezőgazdaságból akar élni, ne csak tehenész lehessen más telepén”. In: Kovács K. (szerk.): Földből élók: Polarizáció a magyar vidéken. Argumentum, Budapest, 370-393.

Harcsa I. (1994): Parasztgazdaságok, mezőgazdasági vállalkozók. KSH, Budapest https://doi. org/ 10.1080/03066 150.2019.1584190.

Harcsa I. (1995): Farmerek, mezőgazdasági vállalkozók. KSH, Budapest

Harcsa I., Kovách I. (1996): Farmerek és mezőgazdasági vállalkozók. In: Andorka R., Kolosi T., Vukovich Gy. (szerk.): Társadalmi Riport 1996, Tárki, Századvég, Budapest, 104-134.

Harcsa I., Kovách I., Szelényi I. (1994): A posztszocialista átalakulási válság a mezőgazdaságban és a falusi társadalomban. Szociológiai Szemle, 3., 15-44.

Harcsa, I., Kovách, I., Szelényi, I. (1998): The Crisis of Post-Communist Transformation in the Hungarian Countryside and Agriculture. In: Szelényi, I. (ed.): Privatising the Land. Rural Political Economy in Post-Socialist Societies. Routledge, London, 214-245.

Juhász P. (2006): Emberek és intézmények. Új Mandátum, Jelenkutató Alapítvány, Budapest

Koós B. (2016): A földből élők - a mezőgazdaság foglalkoztatási funkciója. In: Kovács K. (szerk.): Földból élók: Polarizáció a magyar vidéken. Argumentum, Budapest, 69- 96.

Kovách I. (2012): A vidék az ezredfordulón: A jelenkori magyar vidéki társadalom szerkezeti és hatalmi változásai. Argumentum Kiadó, MTA Társadalomtudományi Kutatóközpont Szociológiai Intézet, Budapest

Kovách I. (2016a): Földek és emberek: Földhasználók és földhasználati módok Magyarországon. Debreceni Egyetemi Kiadó, Debrecen

Kovách I. (2016b): A földből élők és földhasználati módok Hajdúnánáson. In: Kovács K. (szerk.): Földból élók: Polarizáció a magyar vidéken. Argumentum, Budapest, 472-493.

Kovách I. (2018): Földhasználat és földtulajdon-szerkezet. In: Kolosi T., Tóth I. Gy. (szerk.): Társadalmi Riport 2018. TÁRKI, Budapest, 248-263.

Kovács, K. (2007): Structures of Agricultural Land Use in Central Europe. In: Heinonen, M., Nikula, J., Kopoteva, I., Granberg, L. (eds.): Reflecting Transformation in Post-socialist Rural Areas. Cambridge Scholars Publishing, Newcastle, 87-114. 
Kovács K. (szerk.) (2016): Földből élók: Polarizáció a magyar vidéken. Argumentum, Budapest

Kovács K., Bihari Zs. (1998): Bomlás és sarjadás az agrárgazdaságban. Replika, 12., 177-192.

Kovács K., Bihari Zs. (2000): Változó agrárgazdaság a térben. In: Horváth Gy., Rechnitzer J. (szerk.): Magyarország területi szerkezete és folyamatai az ezredfordulón. MTA Regionális Kutatások Központja, Pécs, 282-297.

Kovács T. (1994): Térségi sajátosságok a földkárpótlásnál. Agrártörténeti Szemle, 1-4., 77-87.

Kovai C. (2016): Önellátó függőség. In: Kovács K. (szerk.): Földből élők: Polarizáció a magyar vidéken. Argumentum, Budapest, $130-153$.

Megyesi, G. B. (2012): Institutions and Networks in Rural Development: Two case studies from Hungary. In: Sjöblom, S., Andersson, K., Marsden, T., Skerratt, S. (eds.): Sustainability and Short-term Policies: Improving Governance in Spatial Policy. Ashgate, Farnham, 217-244.

Megyesi G. B. (2016): A Zalaszentgróti kistérség agrárszereplői. In: Kovács K. (szerk.): Földből élók: Polarizáció a magyar vidéken. Argumentum, Budapest, 268-291.

Mikle, Gy. (2020): Long-term transformation of Hungarian manors: The relevance of the rural restructuring approach and the concept of the precariat. Journal of Rural Studies, 1., 105-112. https://doi. org/10.1016/j.jrurstud.2020.05.003

Mikle, Gy., Randelli, F. (2020): The evolution of rural areas influenced by large-scale farming: four case studies from Hungary. GeoJournal, https://doi.org/10.1007/s10708-020-10245-w

Németh K. (2016): Mobilitási utak egy mezőgazdasági nagyüzem dicsfényében és árnyékában. In: Kovács K. (szerk.): Földból élók: Polarizáció a magyar vidéken. Argumentum, Budapest. 154-179.

Nunally, J. C. (1978): Psychometric Theory. 2d ed., McGraw-Hill, New York

Rácz K. (2016): „Mi itt a földhöz vagyunk kötve...”: Agrárgazdasági folyamatok a Fehérgyarmati térségben. In: Kovács K. (szerk.): Földből élók: Polarizáció a magyar vidéken. Argumentum, Budapest, 444-471.

Schwarcz Gy. (2016): A Böhönyei mikrotérség agrárfolyamatai. In: Kovács K. (szerk.): Földből élók: Polarizáció a magyar vidéken. Argumentum, Budapest, 292-316.

Székelyi M., Barna, I. (2008): Túlélőkészlet az SPSS-hez. Typotex, Budapest

Váradi M. (2007): Utak, elágazások - a közelmúlt falukutatásai. In: Kovács É. (szerk): Közösségtanulmány. Módszertani jegyzet. Néprajzi Múzeum - PTE-BTK Kommunikáció-és Médiatudományi Tanszék, Budapest, 43-68.

Varga Gy. (2004): A magyar mezőgazdaság az idók sodrában. Miniszterelnöki Hivatal, Stratégiai Elemző Központ, Budapest 


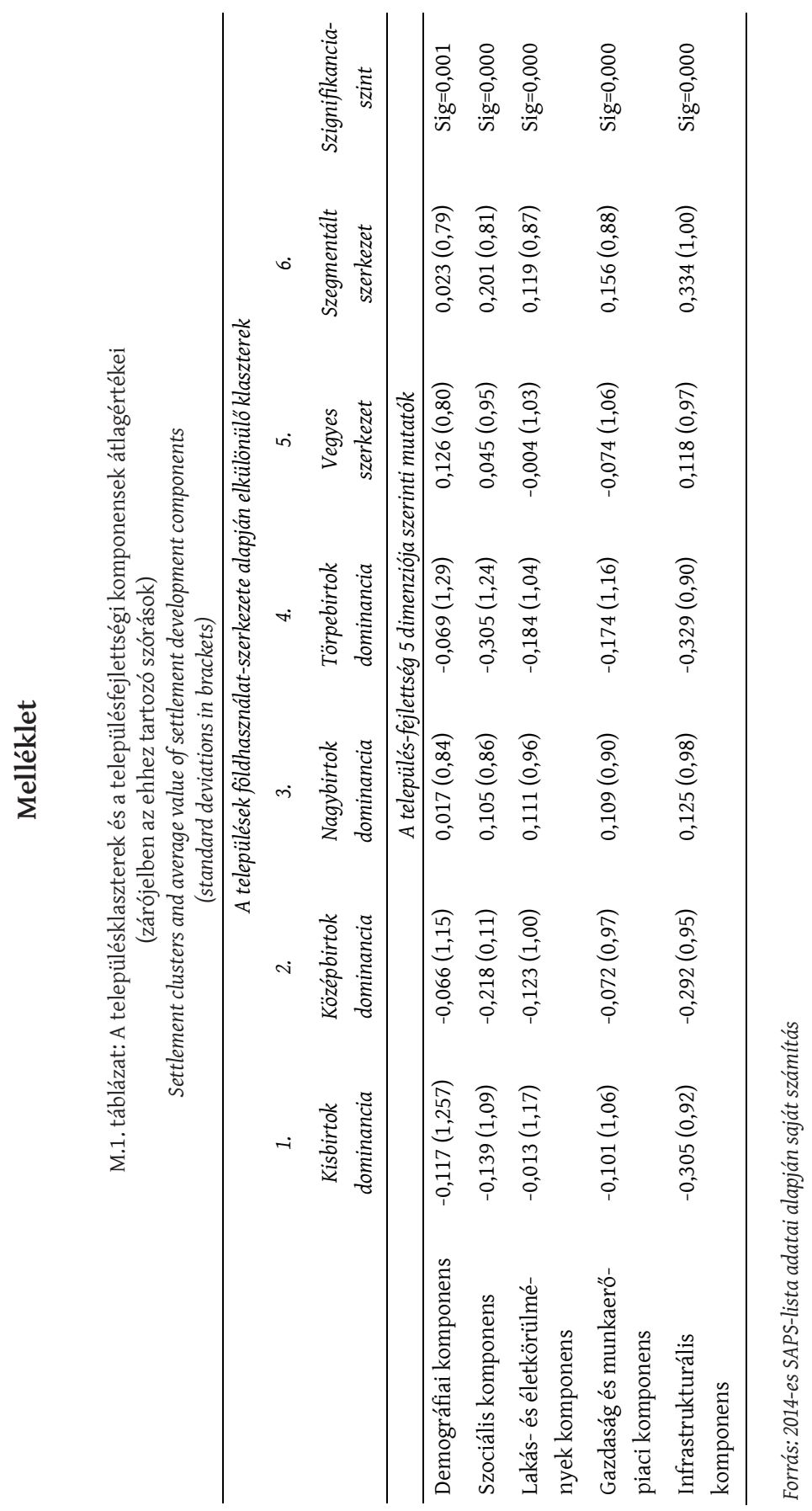




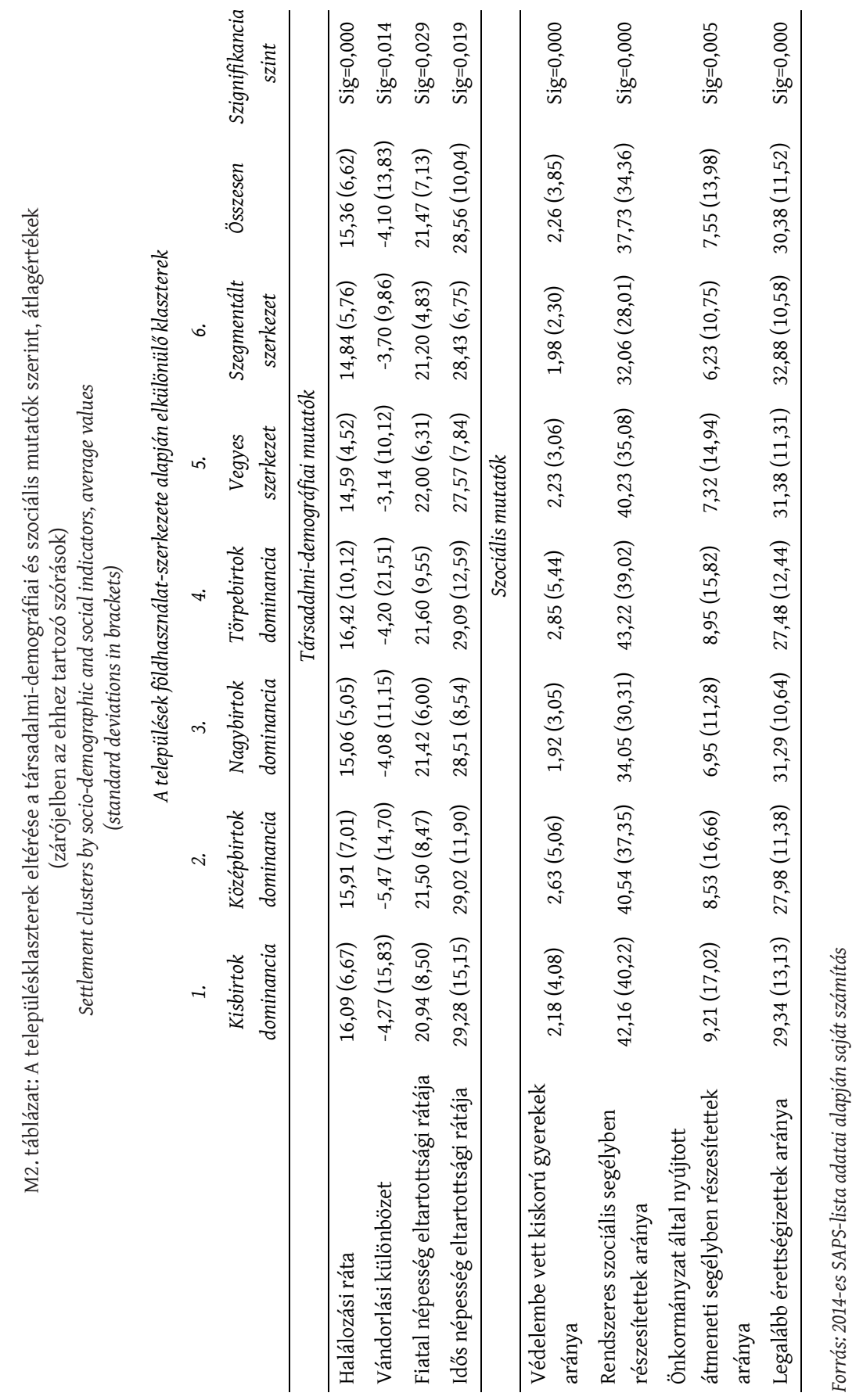




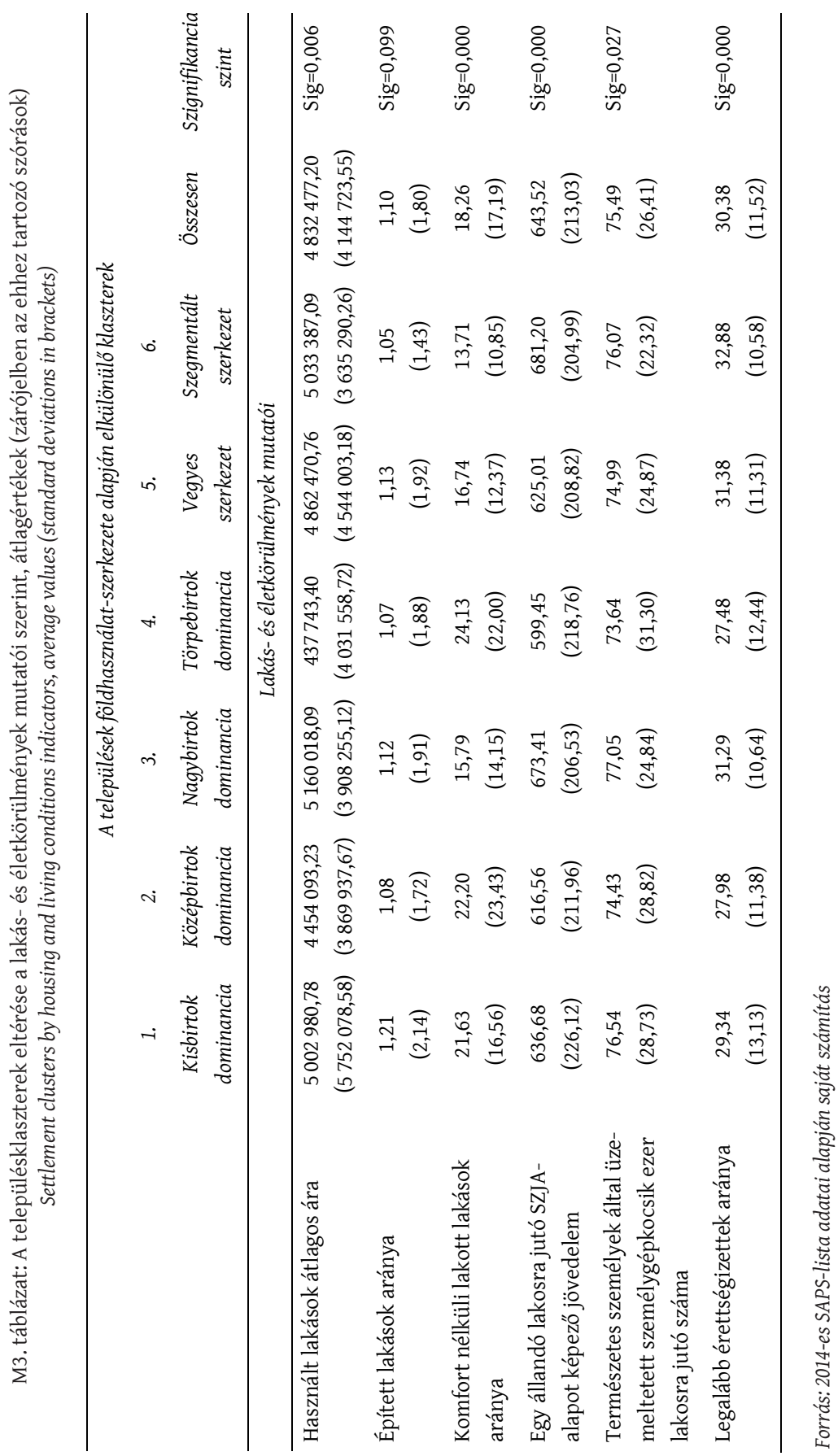




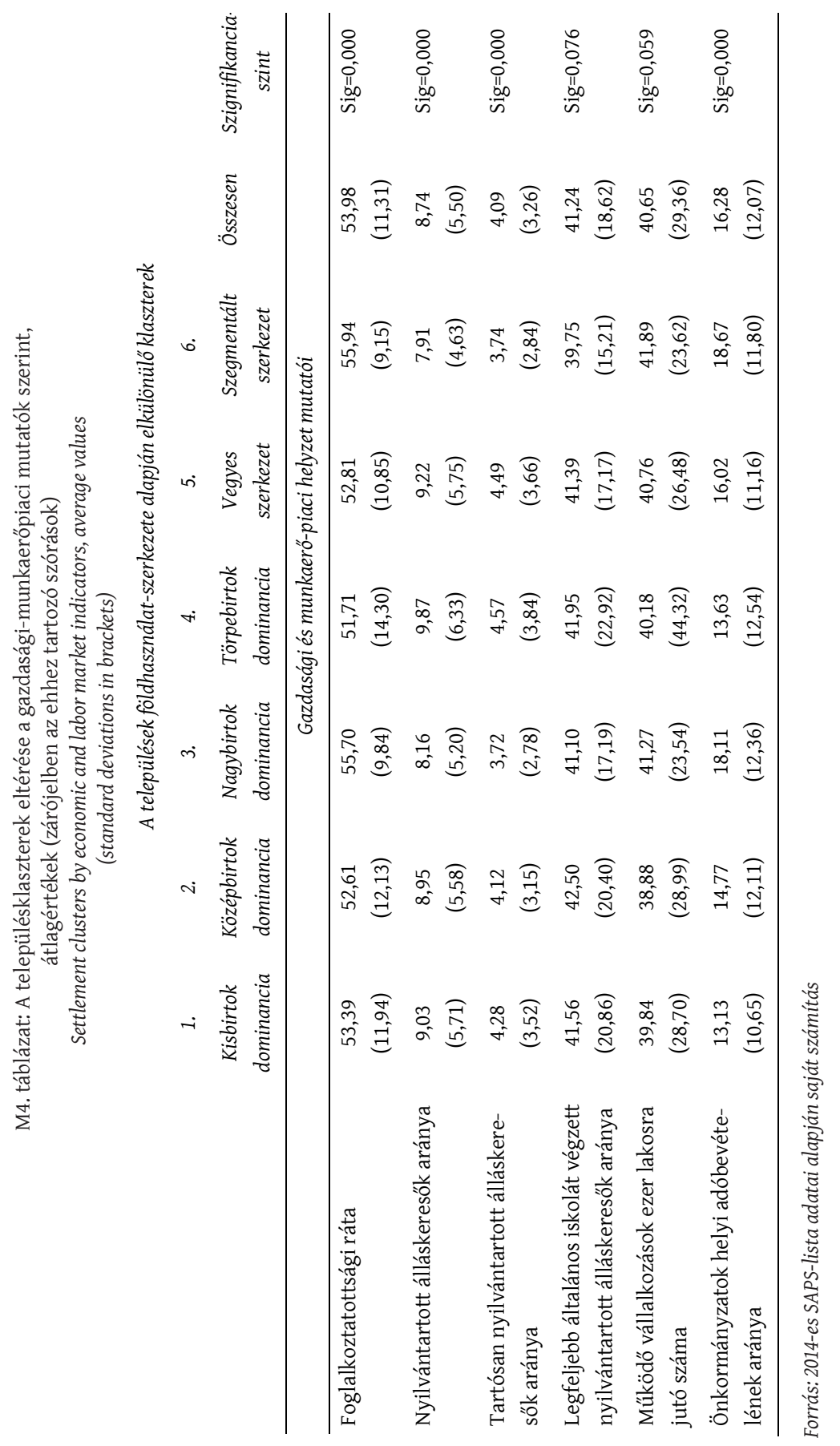




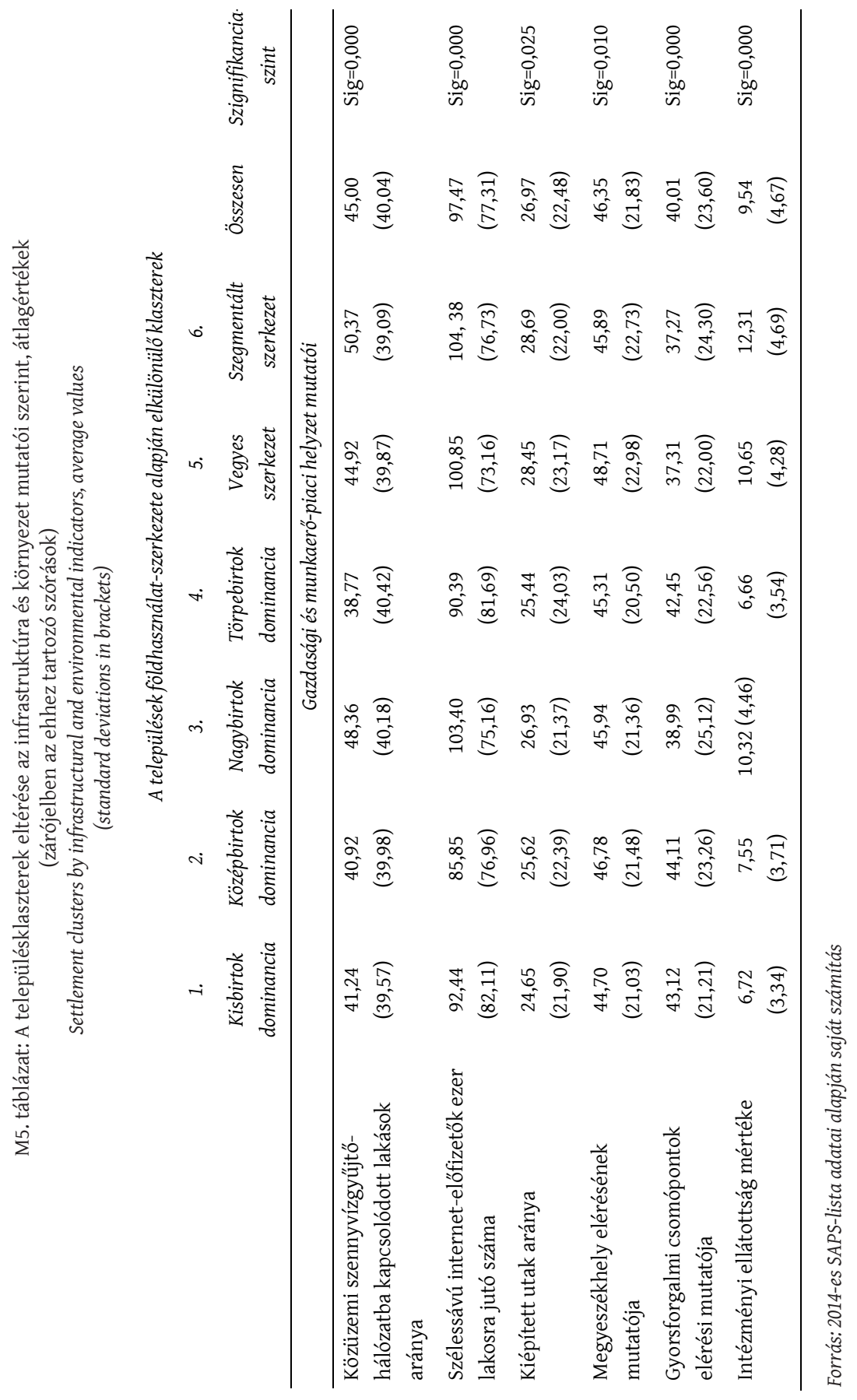

